Teosofia: Indonesian Journal of Islamic Mysticism, Vol. 8, No. 2, 2019, pp. 131-144 e-ISSN: 2540-8186; p-ISSN: 2302-8017

DOI:

\title{
Psycho-Sufistic Therapy of Underground Sufism Movement: A Healing Method Against Punk Community in Jakarta
}

\author{
Abdul Muaz \\ Tasawuf dan Psychotherapy Program of Muhammadiyah University Cirebon \\ muaz@umc.ac.id \\ Adang Darmawan Ahmad \\ Tasawuf dan Psychotherapy Program of Muhammadiyah University Cirebon \\ h.ahmad@umc.ac.id
}

\begin{abstract}
:
The phenomenon of the Punk community in big cities is often neglected by Muslim preachers. The spiritual condition of the Punk community is hardly taken into account nowadays. It is because of stereotypical and pejorative stigmas that make them far from religious values. Therefore, the Underground Sufism movement attempts to approach and invite them to migrate (hijrah) spiritually in gentle and fun ways. This study investigates the psycho-Sufistic therapy applied by the "Tasawuf Underground" movement to the Punk community in Jakarta. This study aims to reveal the Sufistic approach model applied by Underground Sufism in the process of hijrah of the punk community and street children in the capital city of Jakarta to understand their religion and life. This study employs a qualitative description by conducting observation and interviews. The data obtained were then analyzed by using the perspective of Suluk method in Sufism and the humanistic-psychology theory by Abraham Maslow. The results of the study discover that the Underground Sufism movement applied an excellent psycho-Sufistic method that can be used as a role model to deal with punk communities and similar marginalized groups elsewhere.
\end{abstract}

Keywords: Hijrah; Psycho-Sufistic Therapy; Punk Community; Underground Sufism

\section{A. Introduction}

BC Australia, in its investigation, released a report that the Indonesian punk
community is the largest punk group in the world. ${ }^{1}$ Their presence can be
easily found in big cities like Jakarta, Bandung, Yogyakarta, Surabaya, Pekanbaru, and other cities. But, their large population does not give a positive image among Indonesian people. Negative stigmas such as bad boys, nasty, tattooed, dirty,

1 https://m.detik.com/news/abc-australia/d-2763765/kelompok-punk-bawah-tanah-indonesia-terbesardi-dunia. (accessed on 2/11/19). See also https://www.abc.net.au/radionational/programs/360/indonesian-punks/5909858 (accessed 2/11/19). 
broken homes, uneducated, even faithless are common labels we often hear attached to them. In the Indonesian context, this punk community is very diverse from generation to generation including their type, genre, model, lifestyle, motives, and expression. ${ }^{2}$

In general, the punk community is a group that was born because of their antiestablishment and critical attitude towards the ruler. ${ }^{3}$ Their expression is found in music and dress style. Through music, the punk community voices their rights and "ideology". ${ }^{4}$ And through their dress style, this community conveys specific critical messages to the state and society. ${ }^{5}$ They created their own culture. They created, according to the author, a kind of "manifesto" summarized in three words "do it yourself", with three key drivers: unity, equality, and anarchy. Those cultures and manifesto are then manifested in their music, dress style, and daily lifestyle.

In Indonesia itself, especially in Jakarta, it might be rather difficult to sort and identify the punk community with their revolutionary motivations (socio-political resistance movements), with those who are merely having fun or just following others. Moreover, the Indonesian punk community generally does not want to be exposed by media. ${ }^{6}$ Not surprisingly, if the appearance of the punk community's identity in the capital city is often considered to be part of street children even their numbers are not small. ${ }^{7}$ This type of punk community usually shows up in crowded areas of Jakarta: sometimes under bridges, near terminals, around train stations, in markets, on roadside and sidewalks, and so on. To survive, they like busking or being a parking attendant on the streets, public transportation, in the alley of traditional shopping centers and others. Their blatant appearances like mohawk hair, piercings on the face, tattoos on the body, boots, faded jeans, and shabby jackets, give a more negative image to this community. In some cases, some of these street punks usually show off while they are drunk because of drugs or drinking. ${ }^{8}$ Not

2 Jim Donaghey, "Punk Indonesia: a Brief Introduction", Punk \& Post-Punk, Vol. 6, No. 2, (UK: Intellecbooks, 2017), p. 181-187. For information, Punk \& Post-Punk is an international scientific journal deals specifically with the punk community. The writers are not only academicians, but also journalists, artists, and activists who are interested in the study of punk in various scientific aspects.

3 The word "punk" stands for "public united not kingdom" and first appeared in London, England. Mukhlis, Alma Yulianti dan Ina Sakinah, "Ketertarikan Remaja Terhadap Komunitas Punk", Psymphatic, Vol. VI, No. 2, 2013, p. 836-839.

4 One distinctive feature of the music is punk-rock with critical lyrics, a resistance to national and dominant culture. Muhammad Fakhran Al-Ramadhan, "Punk Di antara Dua Budaya: Kajian Ideologi Budaya Populer dalam Dinamika Lokal-Global”, (Jakarta: Proceeding International Seminar Multicultural and Globaliszation, 2012) p. 56-58.

5 Clothing for the punk community is game symbols. Boots, for example, are a symbol of antioppression and a padlock closed at the waist means independence and cannot be restrained.

6 It is admitted by Effi Punktata, one of punkers in an interview with media daring CNN Indonesia. See https://m.cnnindonesia.com/nasional/20171130230725-75-259405/effi-punktatindonesia-cocokuntuk-punk, (accessed 1 November 2019)

7 Ibid

$8 \quad$ Ibid 
surprisingly, if their position is often considered disturbing local residents so that there is legal action taken by the authorities. ${ }^{9}$

Unfortunately, with such a portrait and identity, not many religious leaders are concerned about this problem. Punk community is actually human beings who have needs and desires like others. They need attention, affection, and self-actualization. Their motivations before joining the punk community basically come from their disappointment and neglect of institutions and systems that they hope could become a solution such as religion, family, social environment, and the state.

Based on the fact above, Underground Sufism could play a role to find solutions. The Underground Sufism Movement was founded by Halim Ambiya, a lecturer of Syarif Hidayatullah State Islamic University (UIN) Jakarta. He is also an editor of Islamic books since 2012 through a special social media page, such as Facebook, ${ }^{10}$ for the purpose of Sufism literacy and religious sciences through Kitab kuning $^{11}$ (Islamic classical text of which the paper colors are yellow). As time goes on, Halim realized that preaching Sufism in cyberspace would be useless as it does not directly reach the community. So, since 2016 , he chose to approach and empower the punk community and street children as he saw poor conditions of punks and street children ${ }^{12}$ who were roaming the streets, on bridges, in terminals, and others as they do not get attention. On the contrary, many people even grumble and keep away from them. ${ }^{13}$ Through the method of "Peta Jalan Pulang/ Home Road Map", he and his Underground Sufism movement then invited the punk community and street children to recognize themselves and their identities. Therefore, it is interesting to observe the Underground Sufism movement, especially this movement occurs in the Capital City of Jakarta and its surrounding areas with all their complex problems.

9 Some of the cases that were recorded by digital footprints include, as stated on the page: https://m.detik.com/news/berita/d-4723430/resah-gelandangan-bakal-didenda-anak-punk-demo-dijalan-gatotsubroto (Diakses 1/11/19), https://www.jpnn.com/news/lihat-nih-belasan-anak-punkbekasi-dijemur-satpol-pp (accessed on 1 November 2019). Therefore, The chairman of National Commission for Children Protection, Aris Merdeka Sirait, argued that punk children must be the responsibility of Social agency of every region. See https://m.republika.co.id/amp/mj6z4t (accessed 1 November 2019).

10 To find out his posts, please visit his Facebook page. Now, the number of his followers has reached 416,000 people.

See https://m.facebook.com/story.php?story_fbid=468214763228463\&id=302548766461731 (accessed 2 November 2019).

11 An interview with Halim Ambiya in the TV program Hitam Putih Trans7, 31 May 2019. https://youtu.be/MzdY9FaNIO0 (accessed 2 November 2019). See also reportage on Kompas TV titled "Tasawuf Underground, Anak Punk Mengaji", https://www.youtube.com/watch?v=Dp4kBrrpMIA (accessed 2November 019).

12 Ibid

13 Ibid

Teosofia: Indonesian Journal of Islamic Mysticism, Vol. 8, No. 2, 2019 
The question is whether the "Peta Jalan Pulang" method which was initiated by the Underground Sufism movement uses Sufism approach? Can this method be called as one of the models of psycho-mystic therapy? Then, what is the real therapy model of psycho-Sufism of Underground Sufism to the street punk communities and street children in Jakarta and surrounding areas? These hypothetical questions would be the main concern of this study.

\section{B. Psycho-Sufistic Therapy and Recent Psychic Problem Response}

To analyze the research subjects, the author uses the approach of suluk (pathway) in Sufism and the theory of self-actualization in humanistic psychology. This interdisciplinary method is the epistemological basis of Psycho-Sufistic Therapy which is commonly developed and used by Sufi-healing practitioners and or graduated students of Sufism and Psychotherapy programs in dealing with current psychiatric problems. Because, both in Sufism and psychology the soul is a central issue that is discussed, studied and analyzed.

In Sufism, the Sufis and scholars define Sufism differently but basically complement each other ${ }^{14}$ such as Imam Al-Qusayri, Al-Ghazali, Al-Junaid, AlIsbahani, Al-Syarwani, Al-Kalabadzi, Fariduddin Attar to contemporary intellectuals who are concerned with the issue of Sufism such as William Chittick, Sayyed Hossein Nasr, and others. From their definitions of Sufism, the author concludes that Sufism is a discipline for Salik (follower of Sufism) to purify their souls and minds through the process of riyadhah ${ }^{15}$ and mujahadah ${ }^{16}$ so that they would be closer to God. Suluk itself is a process of undergoing the practice of tasawwuf by the Salik whether it is conducted through tariqa or not. However, in the process of suluk, it is highly recommended through the guidance of a teacher (murshid/sheikh). In the Qur'an and Hadith, it is said that:

14 The student of KH. Munawir Kertosono Nganjuk and The student of KH. Sholeh Bahruddin Sengonagung, Purwosari, Pasuruan, Sabilus Salikin, Jalan Para Salik, Ensiklopedi Thariqah/Tashawuf, (Pasuruan: Pondok Pesantren Ngalah, 2012), p. 4-6. See also Haidar Bagir, Buku Saku Tasawuf Positif (Bandung: Mizan, 2005), p. 86-88.

15 Sufi Hakim Tirmidzi explained: "Riyadhah means cultivation and separation. The soul prefers enjoyment and satisfaction of lust and pleasure to lust. He is doubtful and is in the heart with the influence of lust. Therefore, the soul must be separated from lust. When separated the soul will be far from lust." See Al-Hakim Al-Tirmidzi, Buku Saku Olah Jiwa, Panduan Meraih Kebahagiaan Menjadi Hamba Allah (Jakarta: Zaman, 2013), p. 40.

16 In online dictionary "Al-Maany", the word mujahadah is derived from the word jaa-ha-da, and one of its derivation is mujahadah an-nafs meaning at-tagallub 'ala syahwatiha (win against lust). https://www.almaany.com/ar/dict/ar-ar/\%D9\%85\%D8\%AC\%D8\%A7\%D9\%87\%D8\%AF\%D8\%A9/ (accessed 5 November 2019). The author defines this word as fight seriously against the enemy within ourselves. 
"O, believers! Fear God and look for intercession (wasilah) to draw closer to Him, and worship (fight) in His way, so that you may be lucky."17

"And those who worship for us (looking for grace), we will show them our ways. And truly, God is with those who do good. "18

"... Then eat of all kinds of fruits and then take the path of your Lord which has been facilitated (for you)." From the belly of the bees, there is a cure for humans. Indeed, in that, there is truly a sign (the greatness of God) for those who think. "19

These verses become one of the guarantees that the process of suluk of the salik is the order of God that has been commanded before. Meanwhile, in a hadith Qudsi, narrated by Imam Bukhari and Muslim it is stated:

"I according to my servant's allegation. I am with him when he makes the remembrance of Me. If he recites Me while alone, I will recite him in Me. If he recites Me in a group, I will recite him in a group better than that (the group of angels). If he approaches me one inch, then I will approach him one cubit. If he approaches me a cubit, then I will draw near to him one fathom. If he approaches me in a walking condition, then I will approach him in a running condition." 20

The Hadith confirms one important method of suluk, namely dhikr. Not surprisingly, if in the tradition of tariqa (school or order of Sufism), dhikr or wirid are routinely recommended by tasawuf teachers (murshid). Before offering dhikr and certain wirids, (candidates) salik must go through phases of suluk. This process is called maqamat ${ }^{21}$ that are Sufistic phases or stages to get closer to God. The Maqamat includes, among others, the stage of repentance, zuhud, patience, gratitude, trust, blessing, mahabah, and makrifat. The Sufis explain that these phases are not uniform. Some even include more varied phases in large quantities. Even so, there are general maqamat criteria used as guidelines such as repentance, zuhud, patience, gratitude, trust, and acceptance. ${ }^{22}$ Referring to those stages of suluk, those Sufi approaches are then constructed to be a Sufi therapy.

17 QS. Al-Maidah (5): 35.

18 QS. Al-Ankabut (29): 69

19 QS. An-Nahl (16): 69

20 HR. Bukhari-Muslim, See Sabilus Salikin.

21 Plural form of maqam (Arabic). See Harun Nasution, Falsafah dan Mistisisme dalam Islam (Jakarta: Bulan Bintang, 2004), p. 53-55.

22 Ibid

Teosofia: Indonesian Journal of Islamic Mysticism, Vol. 8, No. 2, 2019 
Meanwhile, in the psychological approach, this study more focuses on the humanistic psychology method but, to sharpen the analysis the author also completes it with the paradigm of transpersonal psychology (included in the humanistic or neohumanistic psychology). ${ }^{23}$

Broadly speaking, there are three trends in the schools of psychology: psychoanalysis, behaviorism, and humanism. Schools of psychoanalysis (Freud, Mesmer, Charcot, Janet, Adler and so on) and behaviorism (Pavlov, Thorndike, Watson, Skinner, etc.), according to Abraham Maslow, were the two dominant schools in the first half of the $20^{\text {th }}$ century that dominated science. ${ }^{24}$ Both psychoanalysis and behaviorism uncover human psychological symptoms atomically, reductionistically, deterministically, materialistically, and mechanistically. If psychoanalysis believes that a person's behavior can be read through his childhood psychic experiences and unconscious forces within him, then behaviorism believes that human behavior can be examined through the influence of their environment. ${ }^{25}$ For Maslow, it is these two schools of psychology that cause humans to lose meaning in their lives; experiencing a valuelessness. This is as stated by Jalaluddin Rachmat:

"Human life is no longer a product of subconscious impulse as in psychoanalysis, nor is it a product of stimulus-response relationships like in behaviorism. Human life is the product and resultant of the desire to actualize the self within the frame of value the one strives for. When Maslow mentions that psychology must now see spiritual life as a fundamental component of our biological life, he has brought psychology closer to religion. At least he has reconstructed psychology not merely based on modern science. "26

Maslow then divides the level of human needs with the Hierarchy of Needs theory which consists of five levels: physiological needs, a sense of security,

23 For the details, see https://www.ahpweb.org/about/what-ishumanistic-psychology.html, (accessed 5 November 2019), or take a look at http://maslow.org/sub/related.htm, (accessed 5 November 2019).

24 Maureen O' Hara, a chairman of Association of Humanistic Psychology (1991-1992), elaborates "Humanistic Psychology is a contemporary manifestation of that ongoing commitment. Its message is a response to the denigration of the human spirit that has so often been implied in the image of the person drawn by behavioral and social sciences. During the first half of the twentieth century, American psychology was dominated by two schools of thought: behaviorism and psychoanalysis. Neither fully acknowledged the possibility of studying values, intentions and meaning as elements in conscious existence. Although various European perspectives such as phenomenology had some limited influence, on the whole mainstream American psychology had been captured by the mechanistic beliefs of behaviorism and by the biological reductionism and determinism of classical psychoanalysis." Ibid.

25 Jalaluddin Rakhmat, Psikologi Agama: Sebuah Pengantar(Bandung: Mizan, 2003), p. 110-111.

26 Jalaluddin Rakhmat, p. 120. 
compassion (love and belonging), appreciation and confidence (esteem), and selfactualization. ${ }^{27}$

Of the five stages, the self-actualization needs can accommodate the human aspect of human beings and then avoid humans from a number of pathologies of present-day illnesses (despair, alienation, emptiness, mental emptiness, etc.). Moreover, the stage of self-actualization is able to unleash the miraculous potentials of humans and then manifest in everyday life. The theory of self-actualization in humanistic psychology is what the writer would use and combine with the mysticism approach to analyze the movement of Sufism Underground Sufism.

\section{The Method of Underground Sufism and Psycho-Sufistic Therapy}

Currently, hijrah (read: "looks shar'i" and "Islamic") has become a lifestyle. This phenomenon is not only popular among common men but also celebrities. Unfortunately, hijrah which substantially means "returning to the spiritual path to be closer to God" is more interpreted symbolically and literally; it tends to be a banal lifestyle rather than the state of mind and way of life.

For the reason of hijrah, urban middle classes enjoy the "piety" they perceive. Ironically, the urban middle classes perceive the doctrine of hijrah and show themselves with a conservative, puritan and radical mindset. In most cases, the spread of the group's propaganda, the author calls it pseudo-hijrah, uses social media networks, such as Facebook, Twitter, Instagram, and Youtube. ${ }^{28}$ Their understanding and implementation are more likely to use the fiqh paradigm rather than a moral perspective. ${ }^{29}$ Today's "muhajirin" (the people of hijrah) see things in black and white so that destructive actions often occur which are far away from the substantive value of hijrah.

What was initiated by the Underground Sufism movement in preaching to the street punk community in Jakarta is actually the antithesis of the superficial and banal movement. Its method focuses on reforming the heart and soul, not the outward appearance as appears in the trend of hijrah among urban middle classes. Tasawuf Underground first invites the street punk community to change and organize their mind, not their casing. ${ }^{30}$ Such kind of hijrah initiated by Underground Sufism is called the "Peta Jalan Pulang".

\footnotetext{
27 Abraham Maslow, Motivation and Personality (UK: Harper and Row, 1954), p. 35-48.

28 https:/tirto.id/tren-hijrah-anak-muda-menjadi-muslim-saja-tidak-cukup-ds9k (accessed 2 November 2019)

29 See Jalaluddin Rahmat, Dahulukan akhlak di Atas Fiqih (Bandung: Mizan, 2007), p. 51-91

30 https://www.idntimes.com/news/indonesia/margith-juita-damanik/wawancara-khusus-perjalananustaz-halim-mengantar-anak-punk-hijrah (accessed 31November 2019)
}

Teosofia: Indonesian Journal of Islamic Mysticism, Vol. 8, No. 2, 2019 
Halim Ambiya himself in the interview both published in various media and to the author directly via Whatsapp underlined the two important and main directions related to this method (Peta Jalan Pulang) that is the way home to God by teaching religion and the way home to the family by means of economic and social empowerment. ${ }^{31}$

Even so, before applying the method of "Peta Jalan Pulang", what interesting and foundational from the Underground Sufism community is the behavior of friends meaning presenting themselves to street punk community and street children like a friend. Halim stated that treating punk children as friends, becoming friends with them, was an effort to make them feel accepted as human beings. Because the appearance of tattooed punk children makes them grumbled, ridiculed, and considered rubbish by the public. The method is by listening to the story of punk children and talking about many things that they really feel. The important point is they feel listened and appreciated as God's creatures like others. ${ }^{32}$

Such endeavor of treating them as a friend, in my opinion, is the first step of the "healing" process for those who feel neglected and marginalized existentially and socially. In a Sufistic study, this practice is part of the moral practices of Salik when undergoing a Sufistic journey. Sheikh Abdul Qadir Al-Jailani in al-Ghunyah Litalibi Tariq al-Haqq stated:

To the strangers (read: those who do not take allegiance to the murshid of the tariqa) who are unfamiliar and outside the circle of the tariqa, the student of tariqa must keep their secrets, look at them with empathetic and loving eyes..."33

Through friendship, the Underground Sufism movement can at least reawaken the self-awareness of punk children who have been sleeping. It is supposed to be done with compassion and empathy. Not surprisingly, if Sheikh Abdullah Ansari in his book Manazil Sairin ever included Yaqzah (awakening self-awareness) to be the beginning of the earliest steps to undergo maqamat (stations) suluk. Before repenting, a person who wants to undergo a spiritual journey should first awaken from the unconscious. Sheikh Ansari said: "Allah says: 'Say I want to warn you of one thing, that you to see God (sincerely) in two or alone.' To see God here is yaqzah (rising) from negligence

31 An interview for this can be accessed at https://youtu.be/LLjqXf9C2NI (Video Tempo, 26 May 2019), https://youtu.be/Dp4kBrrpMIA (Kompas TV, 15 February 2019), https://youtu.be/0hft2xL6J3c (Detikcom, 4 December 2018) and https://youtu.be/MzdY9FaNIO0 (Trans7 Official, 31 May 2019).

32 Ibid

33 Syekh Abdul Qadir Al-Jailani, Buku Pintar Tasawuf: Memahami Spiritualitas Islam dan Tarekat dari Ahlinya (Jakarta: Zaman, 2012), p. 57. 
and self-weakness. This is the beginning of the heart of a servant of God demanding to be enlightened in his life..."34

True friendship should be carried out with empathy and love. Such kind of friendship, according to Maslow, is one of the fulfillment of the basic needs of humans that is the need for love and belonging in life. That is, from psychological analysis, friendship is a fundamental step needed for someone to find meaning for themselves. In this way, a person will regain his self-confidence. ${ }^{35}$ After the phase of friendship, the method of "Peta Jalan Pulang" of Underground Sufism which contains two main elements can be implemented.

In the interview, the founder of Underground Sufism emphasized that the basic idea of "Peta Jalan Pulang" was inspired and created from the concept of the maqam of repentance (tawba) in suluk tasawuf. Halim Ambiya emphasized:

"Actually, the concept of Peta Jalan Pulang is an introduction to the maqam of tawba in Sufism. But, deliberately I did not use the word "repentance/tawba" or "hijrah" to make it softer. In fact, repentance in language means returning. So that, terminologically I interpret repentance as returning to the base of the path, returning to God with regret for wrongdoing and sin, also returning to our Primordial Agreement as servants while in the spirit ... "36

Further, Halim also stated that he owes thought and wisdom from Sheikh Abdul Qodir Al-Jilani in the book Sirrul Asrar. It was from this book that he found inspiration and conception of the "Peta Jalan Pulang". ${ }^{37}$ Repentance itself, as stipulated in Sirrul Asrar, explained by Sheikh Abdul Qodir Al-Jilani is the first entrance that causes all other maqamat (stations) in suluk to be fulfilled.

"Know, all stations are essentially achieved through repentance. How to repent can only be known from people who know-how and he himself has truly repented. Serious and sincere repentance is the first step in a spiritual path."38

In repentance, as explained by Sheikh Abdul Qadir, a Muslim must do it seriously. He must really intend to return to divine love and intend not to repeat his sins and mistakes so far. A person who repents must cleanse himself from the passions that command evil.

34 Abdullah Ansari, Manazil al-Sairin (Iran: Muasasah Dar al-Ulum, without year), p. 25-26.

35 Abraham Maslow, p. 43.

36 Private interview via Whatsapp (5 November 2019)

37 Ibid

38 Syekh Abdul Qadir al-Jilani, Sirr al-Asrar: Secret of the Secrets, Hakikat Segala Rahasia Kehidupan, (Jakarta: Serambi, 2008), p. 125.

Teosofia: Indonesian Journal of Islamic Mysticism, Vol. 8, No. 2, 2019 
"To fight lust, fight first your animal lust-greedy, excessive sleep, neglectfuland fight the nature of the beast in you: bad, angry, violent, and cruel. Then, abstain from the evil habits of lust: arrogant, jealous, vengeful, greedy, and all physical and mental illness. "

Of course, the call for repentance of the Underground Sufism community to street punk children does not use a direct approach (instructive, rude and didactic); it cannot use the method of the preacher to his people in the mosque. It needs a persuasive and effective way like a spiritual psychologist. Moreover, the first thing needs to be taken is a friendly approach. In this way, the goal is to get the punkers and street children to really understand the way home to God.

Halim himself is a practitioner of the Tariqa Al-Qadiriah Naqsabandiah (TQN), he explained that the first path in the method of Peta Jalan pulang in the Underground Sufism also refers to the TQN model. In this case, he refers to the method of Suryalaya Islamic Boarding School of Abah Anom.

"The first step is by introducing spiritual therapy such as religious recitation, reading the Qur'an, studying Kitab Kuning, and training in dhikr/remembrance as taught in the Suryalaya Islamic Boarding School. This process is known as Inabah. They also practice remembrance such as "Laa Ilaha illallah" and hydrotherapy (bathing for repentance). I did invite them to follow remembrance and practice in the teachings of TQN Suryalaya although the stages and the method of recognition are varied. It is the main key to the success of this program. With the process of dhikr we were guiding, Punk and street children immediately felt the sensation of remembrance, mentally and physically. They feel the serenity and inner peace. The sensation that results from remembrance finally releases them from drug addiction. For me, all the practices of dhikr in another tariqa also have the same benefits. I do not prohibit if there are students joining other tariqa but because my practice is TQN Suryalaya, then I use this model.

Based on Halim's statement, it appears that the content of riyadah and mujahadah in the therapy of Underground Sufism, is a tradition of popular tariqa, the TQN, which has been very familiar and popular this country. One thing that distinguishes this from others: the adherents of this group and therapy are not called "ikhwan or brothers (as TQN members who have given allegiance to their murshid). For this reason, Underground Sufism uses a modification of stages and packaging so that street punk groups want to recognize themselves and their God again. At this point, Underground Sufism is carrying out its mission that is introducing the teachings of Sufism must down to earth. Religion does not only belong to certain circles and 
people but also greets anyone who really wants to return to Him. ${ }^{39}$ Not surprisingly, since this method was implemented, many punk communities began to come to ask for guidance and counseling. The success rate also reached $80 \%{ }^{40}$

The great interest of the street punk community indicates that this group has a transcendental desire to live a more valuable life. The emptiness of spiritual values that they have been seeking at least is accommodated in the Underground Sufism. Maslow said, as cited by Jalaluddin Rahmat, the valuelessness is the result of modern science neglecting personal values in human life so that many people are deprived of the noble values they hold. ${ }^{41}$ Personal experience is gone replaced by a generalization and positivistic viruses that have been so strongly embedded in modern science and then affect the patterns of humans interaction with others. ${ }^{42}$

Later, in the second path of the "Peta Jalan Pulang", Halim emphasized the non-religious aspects, namely the economic and social empowerment stage. This stage is the endeavor of Underground Sufism to actualize the extraordinary potentials of the punk community in Jakarta. ${ }^{43}$ In an interview with the author, Halim stressed the matter of the second path as follows:

" What I mean by the second path is economic and social empowerment through entrepreneurship training. I think this concept is commonly used by social activists. The difference is underground Sufism is not a foundation or institution (NGO) whose programs are run based on budget readiness but based on social participation and friendship in the community of Sufi practitioners. So the basic movements are based on friendship among individuals, not institutions" ${ }^{44}$

The second stage of the method of "Peta Jalan Pulang", according to the authors, is part of fulfilling the basic human needs in Maslow's humanistic psychology i.e. self-actualization needs. This phase is part of the guidance and manifestation of

39 An interview with Halim Ambiya at Trans7 Official, https://youtu.be/MzdY9FaNIO0 (Trans7 Official, 31 May 2019). ${ }^{41}$ Ibid

40 Ibid

41 Jalalauddin Rakhmat, p. 119.

42 In one of his books which has been translated into Indonesian, Maslow stressed: "My thesis is that experiential knowledge is prior to conceptual, but the two are hierarchically integrated and need each other. No one dares to specialize too much into either of these two types of knowing. Science with a soul left in it can be shown as more powerful than the science that discards experience data" Lihat Abraham Maslow, Psikologi Sains (Bandung: Mizan, 2004), p. 67.

43 See https://www.idntimes.com/news/indonesia/margith-juita-damanik/wawancara-khususperjalananustaz-halim-mengantar-anak-punk-hijrah (accessed 31 November 2019). See also an interview with Kompas TV at https://youtu.be/Dp4kBrrpMIA.

44 Private interview via Whatsapp (5 November 2019)

Teosofia: Indonesian Journal of Islamic Mysticism, Vol. 8, No. 2, 2019 
human natural character based on the capacity and skills he/she possesses and desires. In his book, Motivation, and Personality, Maslow describes:

"A musician should make music. A painter should paint. A poet should write poetry. He finally makes peace and comfortable with himself. That is how a person becomes who he is. He must be honest with his own character. We can call this as self-actualization need."45

Based on the reports on Underground Sufism, we could see the concrete evidence that this second phase has been actually implemented. Halim along with volunteers from Underground Sufism trained and empowered the street punk community; he coached and bridged the potentials of Jakarta punk youth entrepreneurs. Some become baristas at self-made coffee shops, some become screenprinting entrepreneur, some become musicians and others. This second phase of therapy is a positive self-actualization practice and is rarely noticed.

Finally, after the punk community is guided spiritually, if they return to their family and the community, they would get positive response and appreciation. Because the motivation of the realization of the second stage is in order that the return of street punkers in their respective environments will no longer be stigmatized negatively. The author himself sees the second stage of the return journey passed by the Jakarta punk community as part of cultivating, activating, and re-broadcasting social piety which is increasingly being eroded by capitalistic, consumptive, and digital culture in the capital city of Jakarta.

\section{Conclusion}

Underground Sufism movement introduces the method of "Peta Jalan Pulang" which can be an alternative to Psycho-Sufistic Therapy for urban people who are often marginalized by the state, society, and religious institutions. Psycho-Sufistic Therapy of Underground Sufism takes the method of tasawwuf in the tradition of the Qadiriyyah-Naqsabandiyyah Sufi Order and applies psychic therapy in the discourse of humanistic psychology even though it is not explicitly stated. The method of "Peta Jalan Pulang" of Underground Sufism can be applied to overcome similar cases of street punk communities in other big cities.

Finally, a Sufi Faidh Kasyani once said: "Some lazy individuals find it hard to do spiritual practice (riyadah), soul cultivation, and concern themselves in cleansing the soul and character education. Their souls do not like to do that because of ignorance and limitations. They think that the character cannot be changed. The Underground Sufism Movement with its method of "Peta Jalan Pulang" is an

45 Abraham Maslow, p. 46. 
exception. This community movement shows that riyadah and mujahadah which are essentially called suluk in Sufism can actually be transmitted and injected to those who have been neglected in the big city of Jakarta. The idea of Underground Sufism can be an important learning for Psycho-Sufistic Therapists and also for the state and society. 


\section{Bibliography}

Ansari, Abdullah, Manazil al-Sairin, Iran: Muasasah Dar al-Ulum, Tanpa Tahun.

Al-Jailani, Syekh Abdul Qadir, Sirr al-Asrar: Secret of the Secrets, Hakikat Segala Rahasia Kehidupan, Jakarta: Serambi, 2008.

, Buku Pintar Tasawuf: Memahami Spiritualitas Islam dan Tarekat dari Ahlinya, Jakarta: Zaman, 2012.

Bagir, Haidar, Buku Saku Taswuf Positif, Bandung: Mizan, 2005.

Kasyani, Faidh, Etika Islam Menuju Evaluasi Diri, Jakarta: Sadra Press, 2014.

Maslow, Abraham, Motivation and Personality, Inggris: Harper and Row, 1954. , Psikologi Sains, Bandung: Mizan, 2004.

Nasution, Harun, Falsafah dan Mistisisme dalam Islam, Jakarta: Bulan Bintang, 2004.

Rakhmat, Jalaluddin, Psikologi Agama: Sebuah Pengantar, Bandung: Mizan, 2003. , Dahulukan akhlak di Atas Fiqih, Bandung: Mizan, 2007.

Student of KH. Munawir Kertosono Nganjuk dan KH. Sholeh Bahruddin Sengonagung Purwosari Pasuruan, Sabilus Salikin, Jalan Para Salik, Ensiklopedi Thariqah/Tashawuf, Pasuruan: Pondok Pesantren Ngalah, 2012.

Tirmidzi, Al-Hakim, Buku Saku Olah Jiwa, Panduan Meraih Kebahagiaan Menjadi Hamba Allah, Jakarta: Zaman, 2013. 